\title{
The Translation Problems of Religious Onomastic Units in the Phraseological Layer of the Language
}

\author{
Radjabova Marjona Akhmadovna \\ The Teacher of Bukhara Engineering-Technological Institute, Bukhara, Uzbekistan
}

\begin{abstract}
:
In this article the author has analyzed the religious onomastic components in the structure of phraseological units of English, Russian and Uzbek languages, and also, citing the views of scientists about translations preserving the national features of onomastic units into unrelated languages and expressed the attitude towards them. In addition, it is discussed the role of onomastic units in translation studies as well as, their functions in the structure of phraseological units.
\end{abstract}

Keywords: Onomastic component, Religious, Phraseological unit, Cain, Abel, Noah, God, Judas.

\section{INTRODUCTION}

Translation has been a means of communication between nations and people for many years playing an important role in obtaining information about the culture and many years history of two or more nation representatives. Nowadays the role of translation is increasing in the development of a nation and society too. Through translation, different nations can get an opportunity to get to know about the lifestyle, culture, history and the achievements of the society of a certain country.

Each nation has it's certain national peculiarities in their speech which is getting down from generation to generation. Among such peculiarities, onomastic units and phraseological units with onomastic components are inextricably linked with the spiritual culture, customs, profession, living conditions, aspirations, attitude to reality of the people of the certain language.

\section{METHODOLOGY}

The issue of onomastic units and phraseological units with onomastic components in translation studies has not been out of the attention of linguists. Translating phraseological units with onomastic components is a complex process for both the translator and the researcher. As G. Salomov said, «translation should be of equal value and of equal quality. Therefore, the translator must also be an «equivalent creator» who can compete with the author» $[18 ; 49]$.

In recent years, the number of studies devoted to the translation of national colloquial phraseological units has increased. In these studies, the national-linguistic features of phraseological units are studied comparatively within two or three languages. For example, the works of G.I. Mansurova, F.S. Azizova,

L.E. Kholmuradova, Sh.P. Rakhimova, Z.K. Teshaboyeva, N.A. Tukhtakhodjaeva, N.N.Sidikova, M.A. Radjabova are among them.

In the process of translation, the national character of phraseological units must be preserved, as the linguist Z. K. Teshaboyeva said, «each stable phraseological unit allows the reader to obtain information about historical figures and events as well as memorizing them» $[21 ; 17]$.

\section{RESULTS AND DISCUSSION}

Onomastic units were initially used in their own meaning, but, later it gave symbolic meaning being a part of phraseological units. For example, in her researches O.K. Mjelskaya expressed Иуда as a 
symbol of betrayal, Авель as a symbol of innocent victim, Фома as suspicious or stubborn [9; 8-9]. In fact, based on the legends from the Bible, Иуда comes from the name Искариот, the apprentice of Jesus. He betrayed his mentor Jesus and, thus, has left his name as a traitor in religious teachings. Phraseological units formed out of the name of Иуда is connected with these legends. In the English language, the phraseological unit «(a) Judas kiss» can be translated as «поцелуй Иуды», but, in our opinion, it cannot be translated as «Иуданинг буссаси» into Uzbek because the symbol of Иуда is not familiar for Uzbek mentality. The phraseological units «(A) Judas kiss», «поцелуй Иуды» can be translated into Uzbek language as «betrayal». Or, if we analyze the symbols Авель and Каин, in the Christian's religious book Bible they are metioned as brothers. In the Islamic religion book Koran it is mentioned as Қобил (Каин) and Хобил (Авель), the sons of Adam. According to religious teaching, Каин (Қобил) kills his brother, putting hand to a terrible sin as murder and leaves the name as «murderer», «criminal» and «traitor» in religious teachings. Later, based on these symbolic names, there have been formed the phraseological units such as «Cain-coloured» «рыжий» - «малларанг» (Каин is described as a person with reddish beard), «(the) brand of Саin» - «Каинова печать» - «жиноятнинг ташқи белгилари».

K. Jurayev says: «If we leave every word that defines the national color without translation, the text becomes extremely nationalized and the reader may even lose himself there. To prevent this, it is necessary to place in the context of specific words that are not so strong in national color, to a certain extent of a neutral nature, so that the situation helps to understand the original word that has not been translated» [3; 53]. Based on these ideas, if we analyze the English phrase «Noah's ark» and its Russian equivalent «Ноев ковчег», the names Noah and Noy are onomastic units that are completely alien to the Uzbek nation. Therefore, for a translation to be successful, the translator must have knowledge of the culture, history, art, and folklore of the people of the target language. Only then will the translation have a pure, national character. Only a translator who is aware of the religious teachings of the people understands that the names Noah and Noy should be translated into Uzbek as Noah. However, if the above mentioned phraseological units are literally translated into Uzbek as «Noah's Ark», relativity can arise. The story of «Noah's Ark» is mentioned in the Bible and in the verses of fifteen Surat an-Noah and Surat al-Ankabut. At this point, if the English «Noah's ark» and its Russian equivalent Ноев ковчег are translated into Uzbek as "ship of salvation", the symbolic meaning can be vividly expressed.

The translation of onomastic components in phraseological units is one of the most difficult processes in translation studies. Cultural ties between nations play an important role in the process of translating phraseological units. Pure, high-level translation requires the delivery of phraseological units through adequate translation. In this case, the onomastic components of the equivalent structure express the mental characteristics of the people who speak that language. Therefore, «the translator has two main tasks: the first is to correctly and deeply understand the meaning of the original (language of the work being translated), and the second is to accurately and completely express this meaning in the translation» $[8 ; 153]$.

Translation scholars G.Salomov and N.Kamilov emphasize that the art of translation is not the art of exact repetition of the original, but the art of restoration, re-creation of the work in another language [19; 39]. Indeed, while linguistic units are translated from one language to another on the basis of this idea, linguistic units are the product of a re-creation of the creative style and the translator's knowledge of the nation's customs, lifestyle, history and culture.

When phraseological units with an onomastic component are translated into another language while retaining their national characteristics, it becomes possible to identify the difficulties encountered in the translation process through comparative analysis. 
G. Salomov analyzed the proverb «Яхшилик қил дарёга от, балиқ билар, балиқ билмаса, Холиқ билар» in his book «Рус тилидан ўзбекчага мақол, матал ва идиомаларни таржима қилиш масаласига доир». According to him, in the Russian translation of this proverb «Сотвори добро и брось в воду, вода не примет - рыба примет, рыба не примет - творец примет» the words water, fish and creator do not fit each other [17; 46-47]. In this case, religious phrases cannot be replaced with equivalents, thus, it should be translated word by word because the name Холиқ (as one feature of Allah) is familiar only for those who follow Islam religion. Translated phrase «Холиқұ» is replaced by the word «Бог» in the Russian version as «Холиқұ» has a meaning of «a creator». Here, even when the phraseological unit is translated literally, the meaning of the phrase is preserved in its entirety.

As G.Salomov writes, «If idioms contain words used in a narrow local sense, reflecting the features of toponymy, embodying the specific customs and rituals of the people in a narrow range, painted in national color, they cannot be equivalent to idioms in other languages, even if they are similar in content or close to each other» $[18 ; 66]$. That is, a toponym or anthroponym is present in the phraseological layer of the language, and although they are translated by a phraseological unit that is logically consistent in transmission in non-related languages, they do not always fit each other fully and are not translated while preserving the same onomastic unit. In this respect, the problems encountered in translating onomastic phraseological units into unrelated languages stem from their mental nature.

\section{CONCLUSION}

In conclusion, the comparative analysis of phraseological units of national character in the system of non-related languages plays an important role in finding solutions to the problems of translation and improving the professional skills of future translators. Besides, the onomastic components found in the structure of phraseological units are considered national language units that represent the character of the nation.

\section{REFERENCES}

1. Azizova F.S. (2018). Lingua-cultural features of teaching phraseological units in the Uzbek language to the students of higher education establishments (under the examples of English and Uzbek languages): The dissertation thesis (PhD). - Tashkent, $-56 \mathrm{p}$.

2. Kholmuradova L.E. (2017). Thematic-ideographic interpretation of figurative and motivated phraseology in the English and French languages (linguocultural aspect): The dissertation thesis $(\mathrm{PhD})$. - Tashkent, $-50 \mathrm{p}$.

3. Jurayev K. (1982). The art of translation. - Tashkent: Science, -60 p.

4. Kurbonov A.K., Toshpulatov H. (2021). Problems of teaching linguistic skills in technical universities and ways to solve them // Materials International Scientific and Practical Conference «Philology: from theory to Practice». - Nukus, - P. 101-103.

5. Kurbonov A.K., Hafizov Sh. (2021). Formation of communicative competence of students in teaching Russian // Materials International Scientific and Practical Conference «Philology: from theory to Practice». - Nukus, - P. 104-105.

6. Kurbonov A.K. (2021). The use of the Internet technologies in the implementation of offline teaching a foreign language to students of non-linguistic universities // Globus: Psychology and Pedagogy. - Russia, St. Petersburg, - P. 19-21.

7. Mansurova G.I. (2006). Cognitive aspect of translation of phraseological units: The thesis of the diss. for the cand. phil. sciences. - Ufa, $-29 \mathrm{p}$. 
8. Mirzayev I. K. (2017). The problem of alternative in translation // Communicative approach in teaching foreign languages: language, thinking, culture. Collection of materials of the Republican Scientific and Practical Conference. - Bukhara, - P.153.

9. Mjelskaya O.K. (2008). Semantic specialization and conceptualization of concepts (on the material of onomastic components of biblical phraseology): The thesis of the diss. for the cand. phil. sciences. - Barnaul, -20 .

10. Radjabova M.A. (2019). Comparative study of phraseological units with naming features in nonrelated languages // Philology Matters. - Tashkent, - № 1. - P. 71-80.

11. Radjabova M.A. (2019). Equivalence of phraseological units with onomastic components as the means expressing cross-cultural communication // American Journal of Research. - USA, Michigan, - № 7-8. - P. 314-321.

12. Radjabova M.A. (2019). Classification of onomastic units in the phraseological layer of the Uzbek language // International scientific review. LXI International Scientific and Practical Conference. «International scientific review of the problem and prospects of modern science and education». - France, Paris, - № 1 (41). - P. 22-25.

13. Radjabova M.A. (2019). Reflection of national-cultural features in phraseological and paremiological units of the Russian language with onomastic components. // IX International correspondence Scientific and Practical Conference «Modern innovations in the era of globalization: theory, methodology, practice» - Moscow, - № 4 (32). - P. 23-26.

14. Radjabova M.A. (2020). The classification of phraseological units with onomastic components // Scientific reports of Bukhara State University. - Bukhara, - № 6 (82). - P 139-147.

15. Radjabova M.A. (2021). Semantic analysis of phraseological units with onomastic components // Scientific reports of Bukhara State University. - Bukhara, - № 2 (84). - P 106-115.

16. Rakhimova Sh.P. (2019). Linguistic features of translating idiomatic expressions of English into Uzbek: The dissertation thesis $(\mathrm{PhD})$. - Tashkent, $-48 \mathrm{p}$.

17. Salomov G. (1961). Concerning the translation of proverbs, sayings and idioms from Russian into Uzbek. - Tashkent: «Teacher», - 159 p.

18. Salomov G. (1983). Translation concerns. - Tashkent: «Literature and Art», - 192 p.

19. Salomov G., Komilov N. (1979). Friendship bridges. - Tashkent: «Literature and Art», - 139 p.

20. Sidikova N.N. (2021). Study of pereonimes in the Uzbek languages // Academicia: An International Multidisciplinary Research Journal. - India, Vol.11 Issue 1, - № January. - P. 1197-1199.

21. Teshaboyeva Z.Q. (2017). Phraseological units in English translations of «Boburnoma» and their national-cultural features: The dissertation thesis $(\mathrm{PhD})$. - Tashkent, $-44 \mathrm{p}$.

22. Toshpulatov H.R., Hafizov Sh.U., Kurbanov A.K. (2021). The use of Internet resources in the process of teaching a foreign languages at non-linguistic universities // Research Leader 2021. «Collection of articles of the International research competition». - Russia, Petrozavodsk: New Science, P. 231-236.

23. Tukhtakhodjaeva N.A. (2017). Representation of lingua-cultures in literary translation (on the example of English and Uzbek languages): The dissertation thesis (PhD). - Tashkent, - $42 \mathrm{p}$.

24. Yuldashev B., Urinbayeva D. (2013). Frequency annotated phraseological dictionary of Uzbek folk epics. - Samarkand, -104 p. 